\title{
Analysis of Merchandise Sales Affecting Operating Profit on CV. XYZ Snack Period 2017 - 2018
}

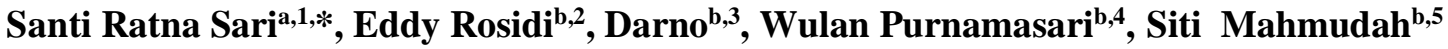 \\ ${ }^{\mathrm{a}, \mathrm{b}}$ Fakultas Ekonomi, Universitas Maarif Hasyim Latif, Sidoarjo, Indonesia \\ ${ }^{1}$ santiratnasari102@gmail.com *; ${ }^{2}$ eddymohamad4@gmail.com; ${ }^{3}$ darno@dosen.umaha.ac.idr; \\ ${ }^{4}$ wulan_purnamasari@dosen.umaha.ac.id; ${ }^{3}$ siti_mahmudah@dosen.umaha.ac.id \\ * corresponding author
}

\section{ARTICLE INFO}

Article History

Received, 30-Sept-2020

Reviewed, 10-Okt-2020

Published, 31-Okt-2020

Keywords

Sales;

Merchandise;

Operating Profit.

\section{ABSTRACT}

This study aims to analyze and determine the effect of sales of merchandise that affect operating profit in the 2017-2018 CV. XYZ SNACK. There are five types of merchandise sales analyzed: sales of seblak fish, sale of tofu crackers, sale of sebasi terasi, sale of cassava chips, and sale of macaroni chips. The study will analyze the positive and significant effect of merchandise sales both simultaneously (F-test, partially (T-test), determinant test for the percentage of influence simultaneously (R-2). Test aids using SPSS version 21.

The test results produce a significant value and the percentage of influence that is in the F Test (Simultaneous) the significant value of (003) means that simultaneously the effect of sales of merchandise affect the operating profit. In the T test (partial) the significance value of cassava chips sales (12.53\%). influence of sales of merchandise affect operating income but not all sales have a significant value, namely the sale of cassava chips on CV. XYZ SNACK period 2017-2018

\section{PENDAHULUAN}

Ekonomis dan meningkatkan nilai-nilai ekuitas untuk perusahaan.pencatatan, dan pengukuran pendapatan dalam PSAK No 23 Revisi 2015 menyebutkan pendapatan di bagi dalam 2 yaitu : pencatatan akrual dan pencatatan dasar kas.

Laba operasi memilki tujuan untuk mengukur penjualan barangan apakah mengalami keadaan yang penjualan baik atau sebaliknya.Glorida (2013 : 15). 2 bentuk laporan Rugi/Laba yakni:

1. Bentuk langsung (single step income statement)

2. Bentuk Tidak Langsung atau bertahap (Multi step income statement)

PSAK 23 Paragraf 14. Pendapatan dari penjualan barang dagangan dapat di iyakan kepemilikannya jika seluruh kondisi berikut dipenuhi :

1. Entitas sudah memindahkan resiko dan faedah kepempemilikan barang secara terpercaya kepada pembeli

2. Entitas tidak lagi melanjutkan pengelolahan yang biasanya terkait dengan kepemilikan atas barang dan melakukan pengendalian efektif atas barang yang di jual.

3. Jumlah pendapatan dapat diukur secara handal

4. Kemungkinan besar manfaat ekonomi yang terkait dengan transaksi penjualan tersebut dapat di nilai secara anda

Tujuan untuk dapat mengetahui pengaruh Penjualan jenis produk terhadap laba operasi pada perusahaan bisa diteliti melalui laporan laba rugi perusahaan. Laporan tersebut menyatakan memang benar seharus terdapat pengaruh antara kedua akun tersebut yaitu penjualan dan laba operasi.

Pengaruh ini dikarenakan ketika penjualan bersih Barang dagangan lebih besar dari pada beban - beban yang dikeluarkan pada saat aktivitas penjualan itu berlangsung . pengaruh utama untuk menghasilkan laba pada perusahaan dagang adalah pada penjualan barang dagangan. Produk 
penjualan yang tepat akan meningkatkan penjualan edan pada laba operasi, beban - beban tersebut menjadi nilai yang akan dikurangkan sehingga sisa yang di hitung tersebut jika mengalami kelebihan maka disebut dengan laba operasi

Dari pembahasan teori yang telah dijelaskan sebelumnya, peneliti membuat alur pemikiran yan digambarkan kedalam kerangka berfikir sebagai berikut:

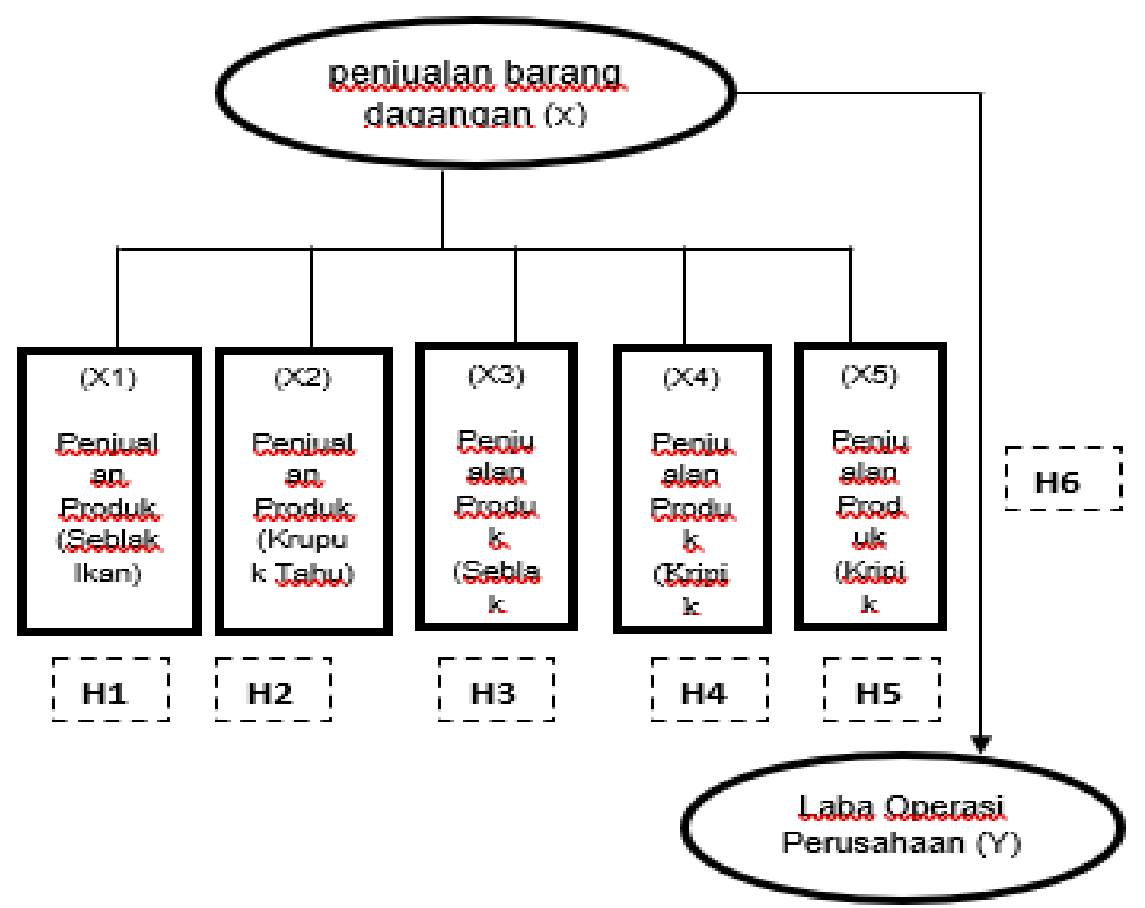

(Sumber :Data Diolah penulis)

Gambar 1. Skema Kerangka Pemikiran

Hipotesis untuk penelitian ini sebagai berikut

H1 :

Penjualan barang dagangan(Seblak Ikan) berpengaruh positif dan signifikan terhadap laba operasi pada CV. XYZ SNACK periode $2017-2018$

H2:

Penjualan barang dagangan (Krupuk Tahu)berpengaruh positif dan signifikan terhadap laba operasi pada CV. XYZ SNACK periode $2017-2018$

H3:

Penjualan barang dagangan (Seblak Terasi) berpengaruh positif dan signifikan terhadap laba operasi pada CV. XYZ SNACK periode $2017-2018$

H4:

Penjualan barang dagangan (Kripik singkong) berpengaruh positif dan signifikan terhadap laba operasi pada CV. XYZ SNACK periode $2017-2018$

H5:

Penjualan barang dagangan (Kripik Tahu) berpengaruh positif dan signifikan terhadap laba operasi pada CV. XYZ SNACK periode $2017-2018$

H6:

Penjualan semua barang dagangan berpengaruh positif dan signifikan terhadap laba operasi pada CV. XYZ SNACK periode 2017 - 2018 


\section{METODE PENELITIAN}

Kualitatif dan kuantitif menjadi pilihan utama Peneliti untuk mencari jawaban atas analisa dan menjawab hipotesis yang di rumuskan. Jenis penelitian deskriptif kualitatif diperoleh peneliti dari observasi dan wawancara di perusahaan yang akan diteliti. Peneliti mengamati dan mencari informasi mengenai data perusahaan yang sesuai dengan penelitian sesuai batasan yang telah di peneliti tentukan dalam waktu yang telah disepakati. data kuantitatif diperoleh peneliti dari menganalisis kegiatan yang sedang berlangsung dengan melakukan uji atau teknik analisis untuk menghasilkan kesimpulan.

1. Variable Independen/Bebas

Sugiyono, (2014: 60) variable penelitian merupakan sifat atau Hal nilai yang bersumber dari Obyek,kegiatan,orang yang ditetapkan oleh peneliti dan diambil hasil kesimpulan. Variable independen/bebas yakni yang mempengaruhi atau menjadi sebab munculnya variable dependen/terikat Sugiyono ( 2016:39).

Tabel 1.Variable Independen/Bebas Penelitian

\begin{tabular}{|c|c|}
\hline $\begin{array}{c}\text { Variable } \\
\text { Bebas }\end{array}$ & Keterangan \\
\hline X1 & Seblak ikan \\
\hline X2 & Krupuk tahu \\
\hline X3 & seblak trasi \\
\hline X4 & kripik singkong \\
\hline X5 & Kripik makaroni \\
\hline
\end{tabular}

(Sumber :Data Diolah penulis)

2. Variable Dependen/Terikat

Variabel Dependen atau Terikat adalah variabel yang dipengaruhi atau sebab adanya variabel independen/bebas. Sugioyono, (2016:39). Variabel dependen dalam penelitianp ini adalah

3. Laba Operasional

Laba Operasi Pada CV. XYZ SNA Operasional Variabel adalah penentuan kontrak atau sifat yang akan dipelajari sehingga menjadi variabel yang dapat diukur Sugiyono, (2016:31).

4. Metode Penentuan Populasi dan Sampel

Penelitian ini yang menjadi populasi adalah perusahaan Penjualan jenis produk di CV. XYZ SNACK.Sampel adalah sebagian dari populasi Sugiyono, (2014: 215). Sedangkan menurut Malhotra dalam Sinambela (2014: 95) sampel adalah sub kelompok dari elemen dari populasi yang dipilih untuk berpartisipasi dalam suatu penelitian.

Sample dalam penelitian ini adalah laporan laba rugi setiap bulan pada Bulan januari sampai dengan desember di tahun 2017 dan tahun 2019.pada sample tersebut akan diambil inti yaitu pada akun penjualan barang dagangan dan laba operasi pada CV. XYZ SNACK.

5. Metode Analisis Data

SPSS (Statistical Product and Service Solution) Versi 23 dengan jenis - jenis uji sebagai berikut:

\section{Uji Statistika Deskriptif}

Mengambarkan data yang digunakan oleh peneliti. Misalnya: mean, median, modus, sum dan standart deviasi. Statistik deskriptif dalam penelitian ini digunakan untuk menggambarkan dan menguji analisa pengatuh penjualan barang dagangan terhadap laba operasi pada CV. XYZ SNACK. 
2. Uji Asumsi Klasik

Uji asumsi klasik yang digunakan oleh peneliti adalah uji normalitas dengan mengunakan Uji Kolmogorov smirnov, Uji Heteroskedastistas gleser, Uji Multikolineritas

3. Teknik Analisa Data

Analisa regresi linear berganda adalah analisa yang jika parameter variable independent/bebas lebih dari satu variable.dua atau lebih variable independen/bebas.

Persamaan Linear Berganda:

$\mathrm{Y}=\mathrm{a}+\mathrm{b} 1 \mathrm{X1}+\mathrm{b} 2 \mathrm{X2}+\mathrm{b3} \mathrm{X3} \ldots .+\mathrm{bn} \mathrm{Xn}+\mathrm{e}$

Keterangan :

Y : Variable Dependent/Variable Terikat (Laba Operasi)

X: Variable Independent/Variable Sebab (Penjualan Jenis Produk)

a : Konstanta

b: Koefisien regresi (besar respon yang di timbulkan oleh perkiraan)

e: eror

4. Uji Hipotesis

1. Uji Pengaruh Secara Parsial (Uji t)

2. Uji Pengaruh secara Simultan (Uji F)

3. Koefisien Determinasi $\left(\mathrm{R}^{2}\right)$

\section{ANALISIS DAN PEMBAHASAN}

Perusahaan CV FAJAR SNACK didirikan pada 5 mei 2019 Perusahaan ini terletak di dusun manunggal kabupaten gresik, jawa timur. Adapum wilayah batasan perusahaan CV. XYZ SNACK sebelah timur yaitu surabaya, sebelah barat mojokerto,sebelah selatan mojosari, sebelah utara lamongan. awal mula pendirian usaha dibidang usaha dagang makanan ringan ini tidaklah langsung berkembang tetapi berkat keinginan semangat dan keyakinan dari pemilik Bapak Ibnu Fajar Shodikin akhirnya berani untuk mendirikan usaha penjualan makanan ringan atau cemilan makanan ringan.

Perusahaan CV. XYZ SNACK merupakan perusahaan yang berfokus pada penjualan makanan ringan. Barang yang dijual antara lain kripik seblak ikan, kripik singkong, krupuk tahu pedas, kripik tahu balado dan jenis makanan ringan yang lain. Pemasaran produk yang dijual ini di jual kepada agen - agen snack, toko-toko jajan, dan warung rumah tangga yang menerima dan menjual snack.

Makanan ringan yang di tawarkan oleh perusahaan Fajar snack.Penjualan barang dagangan melayani partai besar dan eceran untuk memenuhi pasar terutama pada agen-agen snack, toko toko kelontong pemasoknya dari berbagai daerah di gresik, krian ,sidoarjo, surabaya dan mojokerto.

Tabel 2. Barang Dagangan Yang di Jual di CV. XYZ SNACK

\begin{tabular}{|l|c|l|}
\hline \multicolumn{1}{|c|}{ Keterangan } & Harga Per Pack & \multicolumn{1}{c|}{ keterangan barang } \\
\hline Seblak ikan & 6.700 & krupuk bentuk ikan rasa pedas \\
\hline Krupuk tahu & 7.500 & krupuk rasa tahu berbentuk kotak dan panjang \\
\hline seblak trasi & 6.800 & snack berbentuk debek bulat pedas \\
\hline kripik singkong & 8.800 & kripik singkong rasa pedas manis, asin \\
\hline & & \\
Kripik Makaroni & 8.000 & kripik makaroni rasa pedas \\
\hline
\end{tabular}

(Data Olahan Penulis) 
Tabel 3. Jurnal Penjualan CV. XYZ Snack Periode 2017

\begin{tabular}{|l|l|c|c|c|}
\hline \multirow{2}{*}{ Tanggal / Bulan } & \multicolumn{3}{|c|}{ Keterangan } & \multirow{2}{*}{ Jumlah } \\
\cline { 2 - 5 } & Nama Barang & Harga Barang & $\begin{array}{l}\text { Jumlah } \\
\text { Barang }\end{array}$ & \\
\hline Jan-Des 2017 & Seblak Ikan & Rp6.700 & 110.481 & Rp 740.222.700 \\
\hline Jan-Des 2017 & Krupuk Tahu & Rp7.500 & 98.620 & $\operatorname{Rp~739.650.000~}$ \\
\hline Jan-Des 2017 & Seblak Terasi & Rp8.800 & 100.338 & $\operatorname{Rp~882.974.400~}$ \\
\hline Jan-Des 2017 & kripik singkong & Rp8.800 & 87.466 & Rp 769.700.800 \\
\hline Jan-Des 2017 & kripik makaroni & Rp8.000 & 88.589 & Rp 708.712.000 \\
\hline
\end{tabular}

(Sumber CV. XYZ Snack)

Tabel 4. Hasil Uji Stastistik Deskriptif Variable Penelitian CV. XYZ SNACK Descritive statistics

\begin{tabular}{|l|r|r|r|r|r|r|}
\hline & N & Minimum & Maximum & Sum & Mean & $\begin{array}{c}\text { Std. } \\
\text { Deviatio } \\
n\end{array}$ \\
\hline X1 & & & & & \\
X2 & 24 & 8720 & 9900 & 226626 & 9442,75 & 251,805 \\
X3 & 24 & 8000 & 8850 & 202029 & 8417,88 & 247,268 \\
X4 & 24 & 8125 & 8845 & 204061 & 8502,54 & 254,489 \\
X5 & 24 & 7029 & 7965 & 179448 & 7477,00 & 240,772 \\
Y & 24 & 7036 & 8321 & 182661 & 7610,88 & 251,805 \\
Valid N & 24 & 38737 & 41544 & 960425 & $40,017,71$ & 82,970 \\
(listwise) & 24 & & & & & \\
\hline
\end{tabular}

(Output SPSS versi 21 (2019))

\section{Uji Asumsi Klasik}

Hasil Uji Asumsi Klasik Analisa Pengaruh Penjualan barang dagangan terhadap laba operasi sebagai berikut :

\section{Uji Kolmogorov Smirnov}

Diperoleh nilai signifikan $0,634>0,05$. Nilai lebih dari 0,05 menurut ketepan pengambilan keputusan jika nilai signifikan lebih dari 0,05 maka data tersebut berdistribusi normal.

\section{Uji Heteroskedastistas}

Hasil sig sebagai berikut :

1. Variable X1 (Seblak Ikan) Nilai sig 0,189>0,05

2. Variable X2 (Krupuk Tahu) Nilai sig 0,859>0,05

3. Variable X3 (Seblak Terasi) Nilai sig 0,147>0,05

4. Variable X4 (Kripik Singkong) Nilai sig 0,037>0,05

5. Variable X1 (Kripik Makaroni) Nilai sig 0,469 > 0,05Maka dapat disimpulkan bahwa data tersebut tidak terdapat masalah Heteroskedastistas.

\section{Uji Multikolineritas}

Hasil toleransi dan VIF sebagai berikut:

1. Variable X1 (Seblak Ikan) Nilai toleransi $0,552>0,05$ dan, nilai VIF $1,813<10,00$

2. Variable X2 (Krupuk Tahu) Nilai toleransi $0,689>0,05$ dan, nilai VIF $1,452<10,00$

3. Variable X1 (Seblak Terasi) Nilai toleransi $0,528>0,05$ dan, nilai VIF 1,789<10,00

4. Variable X1 (Kripik Singkong) Nilai toleransi $0,673>0,05$ dan, nilai VIF 1,486 < 10,00

5. Variable X1 (Kripik makarani) Nilai toleransi 0, > 0,61505 dan, nilai VIF 1,625<10,00

Maka dapat disimpulkan bahwa data tersebut tidak terdapat masalah multikolineritas 


\section{Uji Hipotesis}

1. Uji Regresi Linear Berganda

Tabel 5. Hasil Uji Regresi Linear BergandaVariable Penelitian CV. XYZ SNACK

\begin{tabular}{|ll|l|l|}
\hline Model & \multicolumn{2}{|l|}{ Unstandardized Coefficients } \\
\cline { 3 - 4 } & (Constant) & 37345,800 & Std. Error \\
\hline \multirow{4}{*}{1} & X1 &, 087 & 2425,163 \\
& X2 &, 065 &, 045 \\
& X3 &, 063 &, 060 \\
& X4 &, 044 &, 065 \\
& X5 &, 057 &, 094 \\
&
\end{tabular}

(Output SPSS versi 21 (2019))

Berdasarkan Tabel Coefficients dapat persamaan Regresi Linear Berganda sebagai berikut:

$$
\begin{aligned}
& \mathrm{Y}=\mathrm{a}+\mathrm{b} 1 \mathrm{X} 1+\mathrm{b} 2 \times 2+\mathrm{b3} \times 3+\mathrm{b} 4 \times 4+\mathrm{b5} \times 5+\mathrm{e} \\
& \mathrm{Y}=37345,800+087 \times 1+0,65 \times 2+0,63 \times 3+0,44 \times 4+0,57 \times 5+e
\end{aligned}
$$

Pemaparan persamaan Regresi sebagai berikut :

1. Konstanta sebesar 37345,800 menyatakan bahwa jika tidak ada jenis (Penjualan produk seblak ikan, Penjualan produk krupuk tahu, penjualan seblak terasi, penjualan kripik singkong, dan penjualan kripik makaroni) maka penjualan sebesar 37345,800.

1) Koefisien regresi $x 1$ Sebesar ,087 menyatakan bahwa, setiap penambahan 1 seblak ikan akan mengalami peningkatan sebesar ,087

2) Koefisien regresi $x 2$ Sebesar ,065 menyatakan bahwa, setiap penambahan 1 krupuk tahu akan mengalami peningkatan sebesar ,065

3) Koefisien regresi $x 3$ Sebesar ,063 menyatakan bahwa, setiap penambahan 1 seblak terasi akan mengalami peningkatan sebesar 0,63

4) Koefisien regresi $x 4$ Sebesar ,044 menyatakan bahwa, setiap penambahan 1 keripik tahu akan mengalami peningkatan sebesar 0,44.

\section{Uji F}

Diperoleh nilai $\mathrm{F}$ hitung sebesar 284 lebih besar dari $\mathrm{F}$ tabel 2,74 dan nilai signifikasi 003 lebih kecil dari 0,05 .dapat tarik hasil kesimpulan yaitu secara simultan//bersama-sama Penjualan produk tersebut berpengaruh terhadap laba operasi.

\section{Uji T}

Uji ini bermanfaat untuk menguji Variable Independen/ bebas dengan variable dependen/terikat secara parsial/individu dengan melihat hasil dari nilai signifikan (sig). Uji ini juga digunakan untuk menguji hipotesis yang telah dibuat apakah diterima atau ditolak.

1) Hipotesis 1 Yaitu penjualan produk seblak ikan berpengaruh positif dan signifikan terhadap laba operasi (diterima).

Table cofficients diatas dapat diketahui hasil nilai sig sebesar 0,001 lebih kecil dari $(0,05)$ pada tingkat signifikasi 5\% dan nilai $\mathrm{T}$ test sebesar 3942 lebih besar dari T tabel sebesar 2101.

Presentase pengaruh secara parsial dilihat dari kolom partial dan nilainya di kuadratkan $, 573^{2}=328,329=32,8 \%$ Hasil dari yang pertama adalah menerima H1 diterima yaitu Penjualan Produk (Seblak Ikan) berpengaruh terhadap laba operasi pada CV. XYZ SNACK periode 2017 - 2018 dan signifikasi terhadap penetuan pada besar laba yaiu siginifikan. 
2) Hipotesis 2 yaitu penjualan produk krupuk tahu berpengaruh positif dan signifikan terhadap laba operasi (di terima)

Pemaparan dari table cofficients diatas dapat diketahui hasil nilai sig sebesar 0,002 lebih kecil dari $(0,05)$ pada tingkat signifikasi $5 \%$ dan nilai $\mathrm{T}$ test sebesar 3822 lebih besar dari $\mathrm{T}$ tabel sebesar 2101.Presentase pengaruh secara parsial dilihat dari kolom partial dan nilainya di kuadratkan $, 521^{2}=271,441=27,14 \%$.

sehingga dapat diambil kesimpulan bahwa secara empiris variable berpengaruh terhadap laba operasi. Hasil dari hipotesis yang kedua adalah $\mathrm{H} 2$ diterima yaitu Penjualan Produk (krupuk tahu) berpengaruh positif terhadap laba operasi pada CV. XYZ SNACK periode 2017 - 2018 dan signifikasi terhadap penetuan pada besar laba yaiu signifikan.

3) Hipotesis 3 yaitu penjualan produk seak terasi berpengaruh positif dan signifikan terhadap laba operasi (di terima)

Pemaparan dari table cofficients diatas dapat diketahui hasil nilai sig sebesar 0,002 lebih kecil dari $(0,05)$ pada tingkat signifikasi $5 \%$ dan nilai $\mathrm{T}$ test sebesar 3858 lebih besar dari $\mathrm{T}$ tabel sebesar 2101. Presentase pengaruh secara parsial dilihat dari kolom partial dan nilainya di kuadratkan $, 547^{2}=299,209=29,92 \%$.

Hasil dari hipotesis yang kedua adalah H3 di terima yaitu Penjualan Produk (seblak terasi) berpengaruh positif terhadap laba operasi pada CV. XYZ SNACK periode 2017-2018 dan signifikasi terhadap penetuan pada besar laba yaiu signifikan.

4) Hipotesis 4 penjualan produk kripik singkong berpengaruh positif dan signifikan terhadap laba operasi (di terima)

Pemaparan dari table cofficients diatas dapat diketahui hasil nilai sig sebesar 0,007 lebih besar dari $(0,05)$ pada tingkat signifikasi $5 \%$ dan nilai $\mathrm{T}$ test sebesar 0,2581 lebih besar dari T tabel sebesar 2101. Presentase pengaruh secara parsial dilihat dari kolom partial dan nilainya di kuadratkan $, 354^{2}=125,316=12,53 \%$.

sehingga dapat diambil kesimpulan bahwa secara empiris variable berpengaruh terhadap laba operasi. Hasil dari hipotesis yang kedua adalah H4 diterima yaitu Penjualan Produk (kripik singkong) berpengaruh positif terhadap laba operasi pada CV. XYZ SNACK periode 2017 - 2018 dan signifikasi terhadap penetuan pada besar laba yaitu tidak signifikan.

5) Hipotesis 5 yaitu penjualan produk kripik makaroni berpengaruh positif dan signifikan terhadap laba operasi (di terima)

Pemaparan dari table cofficients diatas dapat diketahui hasil nilai sig sebesar 0,004 lebih kecil dari $(0,05)$ pada tingkat signifikasi $5 \%$ dan nilai $T$ test sebesar 0,3091 lebih besar dari T tabel sebesar 2101. Presentase pengaruh secara parsial dilihat dari kolom partial dan nilainya di kuadratkan $, 422^{2}=178,084=17.8 \%$.

6) Uji Koefisien Determinasi $\left(R^{2}\right)$

uji koefisien determinasi ( $\mathrm{R}$ square) adalah sebesar 0,526. Hal ini menunjukan nilai bahwa 52,6\% Laba operasi dipengaruhi oleh penjualan produk seblak ikan, penjualan produk krupuk tahu, penjualan produk seblak terasi, penjualan kripik singkong, dan penjualan kripik makaroni dalam penelitian ini. Sedangkan sisanya 47,4\% dipengaruhi oleh variabel lain diluar regresi ini.

\section{SARAN DAN KESIMPULAN}

\section{Kesimpulan}

Penelitian ini memiliki tujuan untuk mengetahui analisis penjualan barang dagangan yang berpengaruh terhadap laba opetasi pada CV. XYZ SNACK pada tahun 2017-2018. Memang penjualan seharusnya menghasilkan laba bagi perusahaan. bagi perusahaan dagang yang memiliki 
banyak jenis barang yang dijual seperti CV. XYZ SNACK ini, haruslah memiliki jenis produk yang tepat dan menguntungkan tentunya maka dari itu peneliti ingin mengetahui penjualan produk jenis mana yang menghasilkan laba yang signifikan.

Berdasarkan beberapa uji yang dilakukan dalam penelitian ini yang menghasilkan hasil uji atas variable independen/bebas yaitu penjualan jenis produk antara lain: penjualan produk seblak ikan, penjualan produk krupuk tahu, penjualan produk seblak terasi, penjualan kripik singkong, dan penjualan kripik makaroni yang berpengaruh terhadap variabel dependent/terikat yaitu laba operasi di CV. XYZ SNACK pada tahun 2017-2018.

Data yang di uji dipilih metode regresi linier berganda pada uji secara simultan/bersama-sama melalui Uji F , uji secara parsial/Individu melalui uji T dan mencari persentase pengaruhnya. melalui koefisien determinasi. secara simultan atau bersama-sama pengaruh penjualan jenis produk yang memiliki pengaruh sebesar 52,6\% terhadap laba bersihnya tetapi pengaruh ini tidak pada semua produk yang memiliki nilai pengaruh yang signifikan. Berikut hasil uji penjualan barang dagangan yang berpengaruh terhadap laba operasi perusahaan. Di urutkan berdasarkan tingkat nilai signifikan yang di hasilkan

1. Hipotesis 1 Yaitu penjualan produk seblak ikan berpengaruh positif dan signifikan terhadap laba operasi (diterima)

hasil nilai sig sebesar 0,001 lebih kecil dari $(0,05)$ pada tingkat signifikasi $5 \%$ dan nilai $\mathrm{T}$ test sebesar 3942 lebih besar dari T tabel sebesar 2101. Presentase pengaruh secara parsial 32,8\% .H1 diterima yaitu Penjualan Produk (Seblak Ikan) berpengaruh terhadap laba operasi pada CV. XYZ SNACK periode 2017 - 2018 dan signifikasi terhadap penetuan pada besar laba yaiu siginifikan.

2. Hipotesis 2 yaitu penjualan produk krupuk tahu berpengaruh positif dan signifikan terhadap laba operasi (di terima)

hasil nilai sig sebesar 0,002 lebih kecil dari $(0,05)$ pada tingkat signifikasi $5 \%$ dan nilai $\mathrm{T}$ test sebesar 3822 lebih besar dari T tabel sebesar 2101.Presentase pengaruh secara parsial 27,14\%. H2 diterima yaitu Penjualan Produk (krupuk tahu) berpengaruh positif terhadap laba operasi pada CV. XYZ SNACK periode 2017 - 2018 dan signifikasi terhadap penetuan pada besar laba yaiu signifikan.

3. Hipotesis 3 yaitu penjualan produk seak terasi berpengaruh positif dan signifikan terhadap laba operasi (di terima)

Hasil nilai sig sebesar 0,002 lebih kecil dari $(0,05)$ pada tingkat signifikasi 5\% dan nilai T test sebesar 3858 lebih besar dari T tabel sebesar 2101. Presentase pengaruh secara parsial 29,92\%. H3 di terima yaitu Penjualan Produk (seblak terasi) berpengaruh positif terhadap laba operasi pada CV. XYZ SNACK periode 2017 - 2018 dan signifikasi terhadap penetuan pada besar laba yaiu signifikan.

4. Hipotesis 4 penjualan produk kripik singkong berpengaruh positif dan signifikan terhadap laba operasi (di terima)

hasil nilai sig sebesar 0,007 lebih besar dari $(0,05)$ pada tingkat signifikasi $5 \%$ dan nilai $\mathrm{T}$ test sebesar 0,2581 lebih besar dari T tabel sebesar 2101. Presentase pengaruh secara parsial 12,53 $\%$. H4 diterima yaitu Penjualan Produk (kripik singkong) berpengaruh positif terhadap laba operasi pada CV. XYZ SNACK periode 2017 - 2018 dan signifikasi terhadap penetuan pada besar laba yaitu tidak signifikan.

5. Hipotesis 5 yaitu penjualan produk kripik makaroni berpengaruh positif dan signifikan terhadap laba operasi (di terima)

hasil nilai sig sebesar 0,004 lebih kecil dari $(0,05)$ pada tingkat signifikasi $5 \%$ dan nilai $\mathrm{T}$ test sebesar 0,3091 lebih besar dari T tabel sebesar 2101. Presentase pengaruh secara parsial 17.8 $\%$. 
Dari hasil pemaparan uji t diatas, maka dapat di ketahui dan diambil kesimpulan bahwa tidak semua variable memiliki nilai yang signifikan terhadap Laba operasi. Dari data diatas penjualan terhadap kripik singkong memang mempengaruhi laba tetapi kurang signifikan dan presentase yang dihasilkan hanya sebesar $12,58 \%$

Dengan demikian penjualan pada penjualan produk seblak ikan, krupuk tahu, seblak terasi, dan kripik makaroni ditingkatkan. Produk kripik singkong dapat beri inovasi rasa atau diganti dengan produk baru yang sejenis dengan produk yang memiliki tingkat pengaruh yang signifikan.

Dari hasil pemaparan uji $\mathrm{t}$ diatas, maka dapat di ketahui dan diambil kesimpulan bahwa tidak semua variable memiliki nilai yang signifikan terhadap Laba operasi. Dari data diatas penjualan terhadap kripik singkong memang mempengaruhi laba tetapi tidak signifikan.

Dengan demikian penjualan pada penjualan produk seblak ikan, krupuk tahu, seblak terasi, dan kripik makaroni ditingkatkan. Produk kripik singkong dapat beri inovasi rasa atau diganti dengan produk baru yang sejenis dengan produk yang memiliki tingkat pengaruh yang signifikan

\section{Saran}

Hasil penelitian ini diharapkan dapat memberikan manfaat sebagai acuan bagi peneliti lain untuk mengembangkan maupun mengkoreksi dan melakukan perbaikan. Serta bermanfaat bagi perusahaan untuk mengetahui pengaruh penjualan jenis produknya terhadap laba operasi yang diperoleh.

1. Pihak Manajemen sebaiknya memperhatikan penjualan pada jenis produk yang lebih signifikan memberikan pengaruh terhadap laba operasi. Penjualan barang dagangan yang signifikan pada penelitia ini terdapat pada penjualan barang dagangan dengan tingkatan signifikan yang diperoleh sebagai berikut : pada penjualan seblak ikan nilai sig $(0,01)$, seblak terasi sig nilai $(0,02)$, krupuk tahu $(0,02)$ dan, kripik makaroni $(0,04)$ Berbeda dengan nilai sig yang diperoleh pada penjualan kripik singkong yaitu sebesar $(0,07)$ artinya penjualan tersebut kurang signifikan.

2. Perusahaan harus berusaha meningkatan laba operasi pada setiap tahunnya dengan cara penjualan barang dagangan yang stabil pada semua jenis barang dagangan. Denga presentase pengaruh penjualan terhadap laba bersih yang diperoleh dalam penelitian ini lebih dari $50 \%$ yaitu sebesar 52,6\% maka seharusnya perusahaan dapat meningkat penjualan barangan selain faktor yang lain diluar penelitian ini semisal : penjualan harga pokok penjualan yang di minimalisir, biaya operasional perusahaan yang di minimalisir,

3. Perusahaan dapat memberikan inovasi barang dagangan yang memiliki pengaruh yang positif dan signifikan. Mennambahkan cita rasa atau kemasan yang lebih menarik untuk para konsumen membeli.

4. Perusahaan juga dapat memperluas jangkauan pasar untuk menambah pelanggan.perusahaan harus bisa memperluas jangkauan pasar yang dicakup. Misal perusahaan dapat merambah pasar ke luar kota-kota besar seperti jogjakarta,madiun, malang atau bahkan merambah ke luar pulau jawa.

5. Perusahaan juga dapat menambah pelangan untuk memperbesar kuantitas penjualan seperti memberikan potongan harga apabila ada pelanggan yang membeli penjualan barang dagangan dengan jumlah yang cukup besar.

6. Memperluas penelitian dengan cara memperpanjang periode penelitian dengan menambah tahun pengamatan dan juga memperbanyak jumlah sampel unt uk penelitian yang akan datang

\section{DAFTAR PUSTAKA}

Pudinshatim Yayah (2016), Kuasai Detail Akuntansi Laba dan Rugi, Bandung: Pustaka Ilmu Semesta

Arief S. Sadiman., dkk (2010), Media Pendidikan, Jakarta: Raja Grapindo Perkasa 
Karyawati Glorinda (2013), Akuntansi untuk non akuntansi, Jakarta: PT Gramedia pustaka Utama Anggota IKAPI

Kariyoto (2017), Analisa Laporan Keuangan, Malang: Universitas Brawijaya Malang Press

Hartono (2018), Konsep Analisa Laporan Keuangan Dengan Pendekatan Rasio dan SPSS, Yogyakarta: GRUB Penernitan CV Budi Utama

Ernita rachmawati (2018), "Pengaruh Kinerja Pembelian Dan Penjualan Terhadap Pencapaian Laba Kotor Di Cv. Anugrah Unika Mekanik (Tahun 2016 - 2018)" , Skripsi. Surabaya: Fakultas Ekonomi Universitas Kristen Petra

Mohamad Rizal Nur Irawan (2016), "Pengaruh Modal Usaha dan Penjualan Terhadap Laba Usaha Pada Perusahaan Penggilingan Padi UD. Sari Tani Tenggerejo Kedungpring Lamongan pada tahun 2016”, Skripsi. Bandung: Fakultas Ekonomi Universitas Komputer Indonesia.

Deris R.P (2015), "Pengaruh Harga Pokok Produksi Terhadap Laba Kotor (Studi Kasus Pada PT. Gudang Garam, Tbk.) pada tahun 2015" , Skripsi. Surabaya: Fakultas Ekonomi dan Bisnis Universitas Adibuana

Sugiono (2014), Metode penelitian pendidikan pendekatan kuantitatif, kualitatif dan R\&D, Bandung: Alfabeta

Dewan Standart Akuntansi Keuangan (2010), PSAK NO 23 (revisi 2009): Pendapatan. Jakarta: IAI 